\title{
Assessment of the Empirical Management Method of Coppice Chestnut (Castanea sativa Mill.) Forests Practiced by the Monks and its Effect on the Availability of Forest Soil Resources in Mount Athos, Greece
}

\author{
Athanasios G. PAPAIOANNOU \\ Aristotle University of Thessaloniki, Faculty of Forestry and Natural Environment, Laboratory of \\ Forest Soils P.O. Box 271, 54124 Thessaloniki, Greece; apapaioa@for.auth.gr
}

\begin{abstract}
In Greece, chestnut forests (Castanea sativa Mill.) occupy more than 30,000 ha of forest land. The species is one of the most significant of the Balkans. It is mainly cultivated for its high quality wood. Concerning cultivation and harvesting, the monks in Mount Athos peninsula in northern Greece practice a special empirical management method for local coppice chestnut forests. Data collected from 9 sampling surfaces, comprising of coppice chestnut stands of three different ages (10,20 and 40 years old), were analyzed to study the effect of this particular empirical management method on specific soil parameters. Results indicated that, there is a general trend for increased organic matter and nutrient concentrations in the soil of 10 and 40 years old chestnut stands in comparison to those of 20 years of age. Cultivation treatments cause intense alterations on soil properties, leading to severe degradation of nutrient resources.
\end{abstract}

Keywords: clear-cutting, forest floor, organic matter, soil nutrients, time-rotation lengthening

\section{Introduction}

Chestnut (Castanea sativa Mill.) forests in Greece occupy 33,081 ha of mostly mountainous land, extending from 400 to $1000 \mathrm{~m}$ a.s.l. considered wild, native ecosystems (National Forest Survey, 1992). The species is characteristic of the warmest ecological zone of deciduous broadleaves (Athanasiadis, 1986). It is best grown under mild, humid and rich in rainfall climatic conditions (Smiris, 1991). Although chestnut grows on a wide variety of soils, its optimal growth is in deep, moderate fertile and acid soils with $\mathrm{pH}$ values ranging between 4.0-4.5 (Kerr and Evans, 1993). However, according to other researchers the optimum $\mathrm{pH}$ value for the species is around 5.5 (Bourgeois et al., 2004). The main reason why chestnut is preferred over other hardwood species is due to the valuable timber produced in relatively shorter rotation times (Kerr and Evans, 1993). A coppicing management system of a short rotation time (12-25 years) is the mostly used management practice for chestnut, in Europe, traditionally (Afif-Khouri et al., 2011). In Greece, most chestnut forests are managed mainly as coppice systems due to the production of valuable timber in short rotation times (2022 years). Nowadays, as the demand for timber of large dimensions increased, there is a trend for the extension of rotation time up to 30-40 years.

During the last years, many management practices of chestnut forests are reconsidered and in some cases adapted to new facts, in order to ensure a long-term protection of soil resources and productivity of the area (Roberts and Gilliam, 1995). Management systems for sustainable forestry should be carefully adapted to the needs and the dynamics of the ecosystem in order to ensure its fertility and productivity (Dyck et al., 1994). The management method practiced on a forest, induces significant alterations both to the stand structure, production of wood as well as forest ecosystem stability (Larsen, 1995). In many cases the effect of the way timber is harvested significantly influences the type of species to be established in the area after logging (Elliot and Knoepp, 2005; Gilliam, 2002).

Management systems and rotation time cause significant alterations to the physical, chemical and biological properties of the soil. This is a fact for almost all the areas around the Mediterranean basin where the effect of human activities is strong on the soil of forest ecosystems i.e. the forests have essentially changed from their original state (Suc, 1984). Slight changes in soil properties independent of human activity observed in some ecosystems are attributed to inner processes of the ecosystem (Papaioannou et al., 2011; Schlesinger, 1990). On the contrary, rapid changes in soil features were observed in the case of human interference (Pernar et al., 2008). The synthesis and productivity of forest stands depend on the soil conditions of a particular area. The nutrient elements in the soil are accumulated either in the organic matter or in the inorganic part of the soil, while in proportion the highest concentrations of nutrients, in forms directly available by the plants are accumulated on the surface soil layers (Auclair and Renzc, 1982; Tandos, 1996). The organic matter content of the soil may represent a major criterion for the measurement of the variations observed nowadays in the disturbed natural forest ecosystems (Prats et al., 1991). 
318

Often these alterations in soil properties are directly related to the growth of the newly established vegetation (Rab, 1996). The forest floor constitutes a significant and constant supply of organic matter and nutrient elements for the soil and therefore the ecosystems. Part of this organic matter reaches the forest soil from degradation and humification procedures as time passes (Duchaufour, 1982). The largest part of the nutrient elements that are absorbed annually from the forest vegetation, return to the soil as plant residues, in the form of leaves, needles, branches of various diameters, fruits, bark etc., or by the permeable rain and crown outflow (Cole and Rapp, 1981). In this way, vegetation contributes in a particularly efficient way to the recycling of the nutrient elements in the forest ecosystems. Nutrient element recycling is limited during the early developmental stages of a stand, because the restoration of organic residues is low. However, it increases as the stand matures. At the best site qualities, the production of plant residues is more abundant and the concentrations of nutrient elements derived from these residues are higher in relation to the worst site qualities (Austin and Vitousek, 1998). Extreme alteration and removal of a forest floor part results in changes to forest soil fertility and productivity (Papaioannou, 1993).

The aim of the present study was the assessment of the empirical management method practiced by the monks of Mount Athos and its effect on soil fertility of the coppice chestnut forest ecosystems.

\section{Material and Methods}

\section{Study area}

The peninsula of Mount Athos, commonly referred as the "Holy Mountain", is located in central Macedonia, northern Greece juts out more than $50 \mathrm{~km}$ into the Aegean Sea and occupies an area of $336 \mathrm{sq} . \mathrm{km}$. Mount Athos land is a UNESCO World Heritage Site, distributed among 20 main Eastern Orthodox monasteries. The region is characterized by an intense terrain, as it is crossed along by a slightly wavy and gradually elevating hill-line with a dense stream and creek net. Altitude ranges from 450 to $990 \mathrm{~m}$ and ends to its southeastern-most extreme at the altitude of $2.033 \mathrm{~m}$, at the abrupt conical peak of Mount Athos (Athanasiadis, 1996; Ganiatsas, 1963).

From a geological point of view, the region belongs to the Serbo-macedonian mass and specifically to the Vertiskos line (Moundrakis, 1985). The north part of the region consists mainly of granodiorite, the central part of gneiss, granites, amphibolites and limestones and the south part of green schists, limestones, marbles and gneiss (Research Institute of Geology and Minerals, 1978). According to Mauromatis (1980), the bioclimate of low regions has a strong semi-mediterranean character. The average temperatures are $5^{\circ} \mathrm{C}$ in winter and $26.5^{\circ} \mathrm{C}$ in summer. Annual precipitation ranges between $510 \mathrm{~mm}$ and 891 $\mathrm{mm}$. Soils are mostly an association of eutric cambisols, according to the WRB (1998).

\section{Management of chestnut forests in Mount Athos}

In Mount Athos chestnut forests occupy a total area of 7,785 ha of forest land (National Forest Survey, 1992). The method chestnut forests are managed almost throughout Greece is usually that of Mount Athos (Moulopoulos, 1963). Actually, this unique empirical method of managing coppice chestnut forests, the so called "agioritiki", is applied by the monks. It starts with clear-cut logging, followed by an initial logging of stump sprouts at the age of 7, called "kathari"; it is a negative selection, aiming at the removal of unwanted sprouts. Then a second logging is carried out at the age of 14-15 which is a positive selection in order to leave the best quality sprouts on each stump. Rotation period is about 20-22 years. At that age, clear-cut logging is performed, with or without retention. When logging is conducted by leaving, 5-10 trees per hectare for an extra rotation period, it aims at the production of large-sized timber by gradual replacement of sprouts with seedlings. Up to now no fertilization or plant disease treatments have ever been conducted.

\section{Sampling design}

The area chosen for the present research is situated at the center of Mount Athos peninsula. Chestnut stands of different ages (10, 20 and 40 years old) co-existed in the particular area, having similar topographic and physiographic characteristics. Each stand of different age occupied a discrete sub-area in which sampling was conducted as follows: in each stand 3 circular experimental plots (circle radius $10 \mathrm{~m}, 314 \mathrm{~m}^{2}$ ) were randomly established. The first three plots consisted of 10 year-old chestnuts, i.e. 3 years after the first site preparation $\left(40^{\circ} 15^{\prime} 8.86^{\prime \prime} \mathrm{N}\right.$, $\left.24^{\circ} 13^{\prime} 36.01^{\prime \prime} \mathrm{E}\right)$. In the next three plots the chestnuts were 20 years old, i.e. reaching the age of logging $\left(40^{\circ} 15^{\prime} 46.80^{\prime \prime}\right.$ $\left.\mathrm{N}, 24^{\circ} 13^{\prime} 34.84^{\prime \prime} \mathrm{E}\right)$. Finally, in the last three plots the trees had the age of 40 years and were not yet logged because according to the management plan when the trees reached the age of 20-22 market demanded timber of larger dimensions $\left(40^{\circ} 16^{\prime} 49.22^{\prime \prime} \mathrm{N}, 24^{\circ} 12^{\prime} 33.16^{\prime \prime} \mathrm{E}\right)$.

Soil sampling was conducted in August 2011. In each of the three experimental plots of each age described above, three sampling points were randomly selected. At each sampling point, the depth of the organic layer was measured and a litter sample was extracted. Samples of forest floor were obtained by pressing a $625 \mathrm{~cm}^{2}$ steel sheet sampling frame $(10 \mathrm{~cm}$ deep $)$ into the forest floor and collecting all organic material above the mineral soil. In each of these samples the horizons $\mathrm{L}$ and F, $\mathrm{H}$ were separated and carefully placed in plastic bags (Papamichos, 2006). Mineral soil was removed after successive sieving. Leaves from the upper third of the crown of at least 10 trees per stand were collected. Samples were pooled to provide two composite samples of foliage. All forest floor and leaf samples were oven-dried to constant weight at $85^{\circ} \mathrm{C}$ and weighed. Litter subsamples were then ground in a Willey mill to pass a 40 mesh stainless steel sieve before being analyzed. 
A $0.25 \mathrm{~m}^{2}$ soil pit was also dug to a depth of $0.6 \mathrm{~m}$ at each sampling point from which disturbed inorganic soil samples (approximately $500 \mathrm{~g}$ each) were extracted from four depth intervals: $0-10,10-20,20-40$ and $40-60 \mathrm{~cm}$. From each stand, samples were collected using a bulk density corer (radius $5.0 \mathrm{~cm}$, height $7.0 \mathrm{~cm}$, total volume 549.8 $\mathrm{cm}^{3}$ ). Bulk density cores were taken from directly beneath forest floor sampling locations. Sprout density and height, stool density, and diameter at breast height $(\mathrm{DBH} \geq 5 \mathrm{~cm})$ were also measured.

\section{Chemical analysis}

Litter and leaves dried at $85^{\circ} \mathrm{C}$ were finely ground and portions (ca. $0.5 \mathrm{~g}$ ) and digested with $\mathrm{HNO}_{3}+\mathrm{HClO}_{4}+\mathrm{H}_{2} \mathrm{SO}_{4} \quad\left(5: 1: 0.5 ; 200^{\circ} \mathrm{C}\right)$ (Alifragis, 2010). The solutions were analyzed for total $P$ colorimetrically using the phosphomolybdenum blue method and for total $\mathrm{Ca}, \mathrm{Mg}, \mathrm{Na}, \mathrm{K}, \mathrm{Fe}, \mathrm{Mn}, \mathrm{Cu}$, and $\mathrm{Zn}$ by atomic absorption spectroscopy (Alifragis, 2010). Total N were determined by the Kjeldahl analysis. The organic matter was determined by loss on ignition at $540^{\circ} \mathrm{C}$ for $5 \mathrm{~h}$ (Alifragis, 2010).

All mineral soil samples were air dried and sieved through $2 \mathrm{~mm}$ mesh screens. $\mathrm{pH}$ was determined on a soil: water suspension (1:1, by weight) using a glass electrode. Soil organic matter was determined by means of wet oxidation (Nelson and Sommers, 1982). Total N was determined by the Kjeldahl method (Stevenson, 1982). Available $\mathrm{P}$ was extracted with $0.5 \mathrm{~N} \mathrm{NaHCO}_{3}$ at $\mathrm{pH} 8.5$ and was measured spectophotometrically by a modified phosphomolybdenum blue method (Alifragis, 2010). Exchangeable $\mathrm{Ca}, \mathrm{Mg}$, $\mathrm{K}$ and $\mathrm{Na}$ were determined by the $\mathrm{CH}_{3} \mathrm{COONH}_{4}-\mathrm{pH} 7$ method (Grant, 1982). The extracted cations were then measured by atomic absorption spectophotometry. Determination of heavy metal concentration was conducted by the DTPA method (Lindsay and Norvell, 1978).

\section{Statistical analysis}

In order to compare the means of several quantitative variables between age classes, we performed one-way ANOVA using SPSS software (Norusis, 2004). In this case, we were interested in testing the statistical hypothesis of the equality of a means population set regarding a 3-level factor (stand age). All comparisons among means were conducted with the Tukey-Kramer HSD test at a significance level of 0.05 .

\section{Results and discussion}

Physiographic and growth characteristics of the stands in the plots for each age group

The plots were designed by taking into account the effect of physiographic and topographic conditions on both tree growth and soil parameters in order to obtain comparable results. All chestnut plots had similar physiographic characteristics (Tab. 1). The number of stools per hectare, which is a non time dependent forestry parameter, shows no significant differences between the three stand age groups studied (Tab. 2), reinforcing our certainty about the homogeneity of the site. This was expected since the number of stumps per hectare remains always stable. On the contrary from the results in Tab. 2 statistically significant differences were detected in the number of stump sprouts per hectare between the age group of 10 year-old and those of 20 and 40 years of age.

The gradual decrease in the number of stump sprouts in 20 and 40 year-old stands is due to cultivation practices resulting from the thinning of the stand for the production of large dimension timber (Smiris, 1991).

\section{Nutrient concentrations of the foliage}

As it is shown in Fig. 1 there are statistically significant differences in the foliar concentration of $\mathrm{N}$ between the stands of 40 years of age and those of 10 and 20 years old $(\mathrm{F}=5.268, p=0.048)$. These increased concentrations of nitrogen in the leaves of 40 year old chestnuts are probably due to the stabilization of leaf-mass and the reduction of crown percentage in proportion to the total biomass (Cole et al., 1990). Phosphate shows significant statistical differences (Fig. 1), with increased concentrations in the 10 and 20 year-old stands in comparison to those of 40 years old $(\mathrm{F}=18.635, p=0.003)$. This can be attributed to greater $\mathrm{P}$ uptake from the soil during the early stages of stand development until equilibrium was reached after the full growth of the stand crowns (Berthelot et al., 2000; Colin-Belgrand et al., 1996). K concentration increases as the trees mature (Fig. 1). Leonardi et al. (1996) recorded higher $\mathrm{K}$ concentration in leaves comparing older to younger chestnut stands. Concentrations of $\mathrm{Ca}, \mathrm{Mg}$ and $\mathrm{Na}$, were not significantly different among the three different age groups of chestnut stands studied. The statistical differences recorded for $\mathrm{Mn}(\mathrm{F}=25.977, p=0.001)$ with increased concentrations at the stands of 20 and 40 years old and $\mathrm{Zn}(\mathrm{F}=8.593, p=0.017)$ in the 20 year-old stands (Fig. 2), do not seem to be of some value and cannot be attributed to a particular factor. On the contrary Fe and $\mathrm{Cu}$ concentrations do not present statistically significant differences among all the different age groups of chestnut stands studied (Fig. 2). According to Vitousek (1997) the

Tab. 1. Physiographic characteristics of the stands in the three plots of each age group

\begin{tabular}{cccc}
\hline Stand age (years) & 10 & 20 & 40 \\
\hline Altitude $(\mathrm{m})$ & 530 & 560 & 520 \\
\hline Exposure & E & W & W \\
Slope (\%) & $15-20$ & $10-20$ & 15 \\
Top soil stoniness (\%) & \multicolumn{3}{c}{ Inappreciable } \\
Erosion & Gneiss \\
Bedrock & \multicolumn{3}{|}{ Mid slope } \\
\hline Topographic position & &
\end{tabular}


320

Tab. 2. Stand age effect (means \pm standard errors) on tree growth parameters and on number of stools and stump sprouts per hectare

\begin{tabular}{cccccc}
\hline Stand age (years) & 10 & 20 & 40 & $\mathrm{~F}$ & $\mathrm{p}$ \\
\hline Height $(\mathrm{m})$ & $9.42 \pm 0.20 \mathrm{c}^{*}$ & $15.08 \pm 0.29 \mathrm{~b}$ & $21.22 \pm 0.35 \mathrm{a}$ & 443.403 & 0.0001 \\
Top height $(\mathrm{m})$ & $11.11 \pm 0.26 \mathrm{c}$ & $16.00 \pm 0.36 \mathrm{~b}$ & $22.06 \pm 0.36 \mathrm{a}$ & 272.872 & 0.0001 \\
DBH $(\mathrm{cm})$ & $8.56 \pm 0.21 \mathrm{c}$ & $15.10 \pm 0.38 \mathrm{~b}$ & $25.04 \pm 0.82 \mathrm{a}$ & 297.536 & 0.0001 \\
\hline Stools $/ \mathrm{ha}$ & $1072.19 \pm 170.84$ & $976.65 \pm 28.09$ & $753.72 \pm 119.63$ & 1.809 & 0.243 \\
Sprouts $>5 \mathrm{~cm} / \mathrm{ha}$ & $4384.29 \pm 594.48 \mathrm{a}$ & $1974.52 \pm 212.05 \mathrm{~b}$ & $1337.58 \pm 247.37 \mathrm{~b}$ & 16.859 & 0.0003 \\
\hline
\end{tabular}

${ }^{*}$ Means in the same row marked with different letters are significantly different

availability of nutrients in the soil is readily determined by their concentration in the leaves.

Foliar nutrient concentration is an important parameter for the assessment of the nutritional status of forests (Hardtle et al., 2005; Sariyildiz and Anderson, 2005). The concentrations of nutrients in the leaves of deciduous species alter during the vegetative period. The concentrations of $\mathrm{N}$ and $\mathrm{P}$ are constantly decreasing during the growth period, initially because of leaf biomass increase until July (dilution) and due to their simultaneous transfer from the leaves to other tree tissues (Cote et al., 2002). K concentration, also presents a constant reduction, mainly due to leaching from the leaves and secondly due to transfer in other parts of the tree. On the contrary to the above, the concentrations of $\mathrm{Ca}$ and $\mathrm{Mg}$ continue to increase during the vegetative period, mainly (Palma et al., 2000; Zhang and Allen, 1996).

\section{Nutrient amounts in the forest floor}

The practice of clear cutting, early in the decade of 1970, raised concerns over a probable long-term reduction of soil fertility due to excessive loss of nutrients by the removal of branch and leaf material (Johnson and Todd,

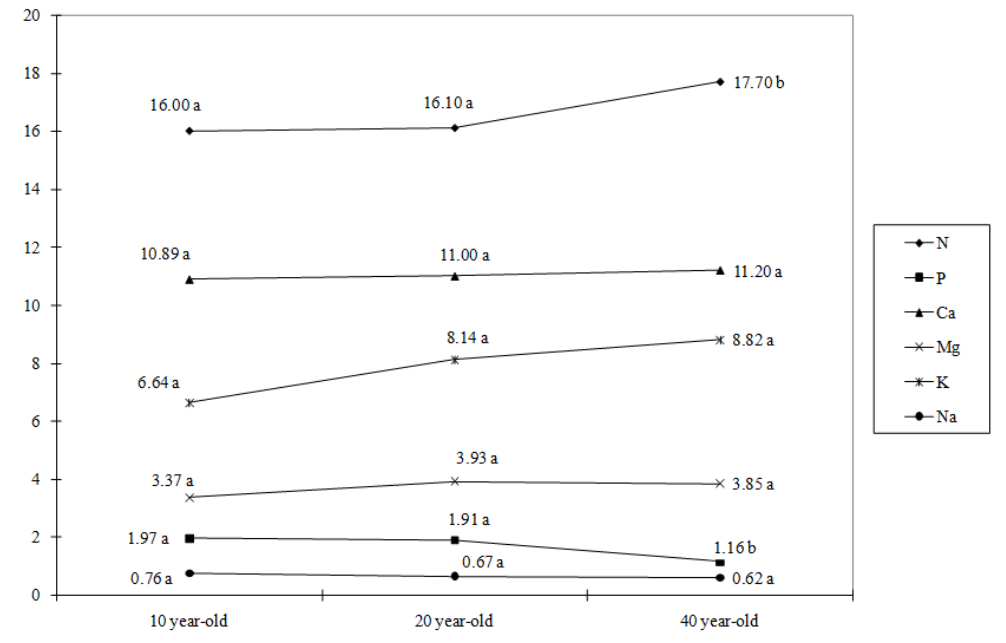

Fig. 1. N, P, Ca, Mg, K and Na concentrations $(\mathrm{mg} / \mathrm{g})$ in fresh leaves

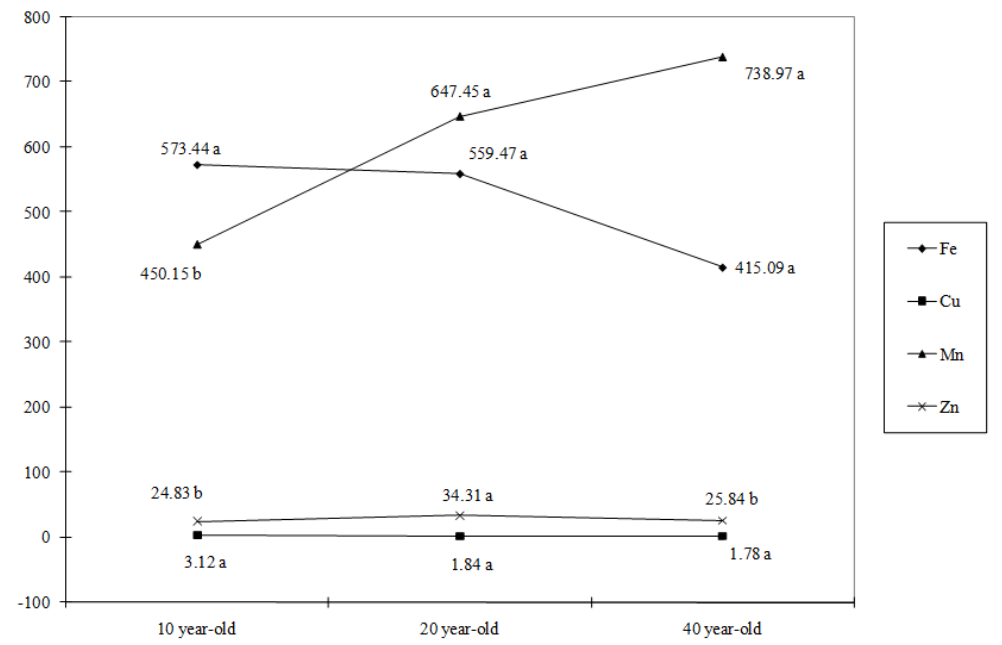

Fig. 2. $\mathrm{Fe}, \mathrm{Cu}, \mathrm{Mn}$ and $\mathrm{Zn}$ concentrations $(\mathrm{mg} / \mathrm{kg}$ ) in fresh leaves 
1998; Walmsley et al., 2009), which can consequently result in the reduction of soil productivity (Chen, 1998).

Nutrient amounts in the forest floor shown in Fig. 3 and 4 are not significantly different among the three age groups of chestnut stands studied except for $\mathrm{Cu}$ (Fig. 4) that presents significantly increased amount in the 40 year-old stands $(\mathrm{F}=3.528, p=0.045)$. This can be probably attributed to minor differentiations of $\mathrm{Cu}$ content in the parent material. This hypothesis is supported by the existence of relatively higher amounts of $\mathrm{Cu}$ accumulated in the soil of 40 year-old chestnut stands (Fig. 8).

The mean content of organic matter in the forest floor for all the three age groups of chestnuts reaches approximately $8000 \mathrm{~kg} / \mathrm{ha}$ (Fig. 5). At the age of 10, this amount derives mainly from the cultivation technique applied (negative selection) at the age of 7 i.e. plant material of younger age and smaller dimensions left on the soil surface. The fact that the content of organic matter remains almost at the same levels at the age of 20 is justified by the application of the cultivation technique (positive selection) practiced at the age of 15 . The cultivation technique resulted on top of the annual accumulation of plant residues, in the addition of older and larger plant material thus extending the duration of decomposition (Tandos and $\mathrm{Pa}$ paioannou, 1999). Finally, the slightly increased content of organic matter of the forest floor at the age of 40 (Fig. 5) derives from the larger production and the different synthesis of plant residues produced in the stands as well as to the equilibrium the system has reached by decomposition conditions. Recent research works report that the type and synthesis of plant residues, as well as the management method of the forest all have significant effects on the decomposition of the forest floor (Li et al., 2009).

Moreover it should be mentioned that all the nutrients (N, P, Ca, Mg, K, Fe, Cu, Mn and $\mathrm{Zn}$ ) were found in lower amounts in the forest floor of 10 year-old coppice chestnut stands compared to 20 and 40 years old. This could be attributed to the higher decomposition rates and release of nutrients in young stands. The intensive nutrient release rates could be due to the favorable decomposition conditions occurring in these younger age stands and furthermore to the nature of the plant residues of early age.

\section{Nutrient amounts in the mineral soil}

Despite the fact that the accumulation of organic matter in the soil (Fig. 6) does not present significant differ-

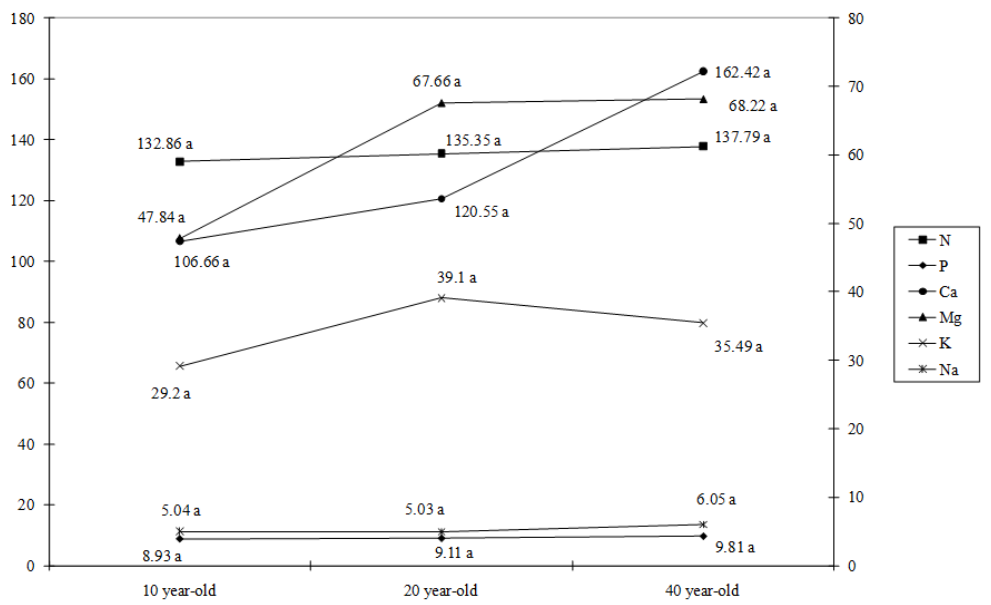

Fig. 3. N, P, Ca, Mg, K and $\mathrm{Na}$ amounts (kg/ha) in the forest floor

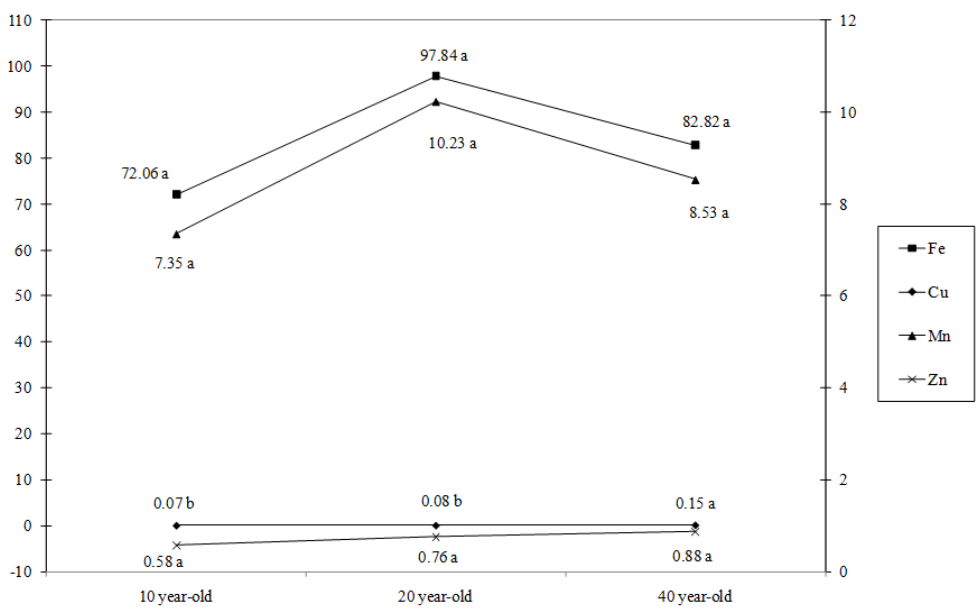

Fig. 4. Fe, $\mathrm{Cu}, \mathrm{Mn}$ and $\mathrm{Zn}$ amounts $(\mathrm{kg} / \mathrm{ha})$ in the forest floor 


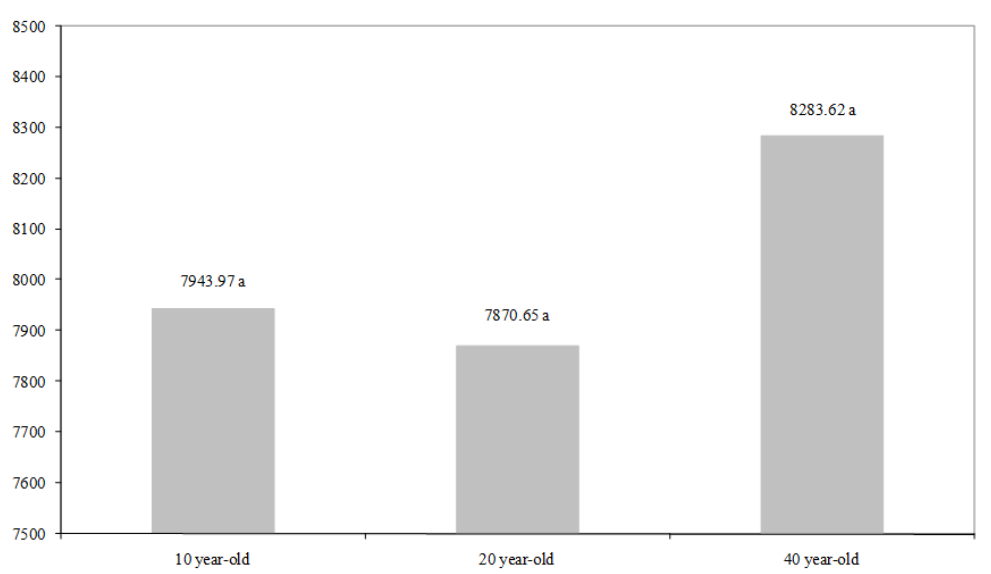

Fig. 5. Organic matter amounts $(\mathrm{kg} / \mathrm{ha})$ in the forest floor

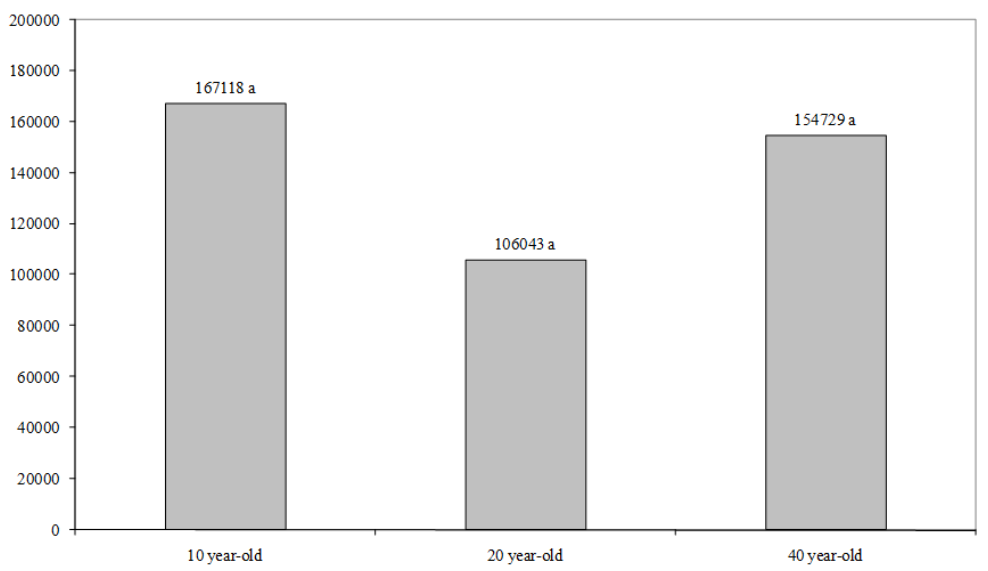

Fig. 6. Organic matter amounts $(\mathrm{kg} / \mathrm{ha})$ in the mineral soil

ences, among the chestnut stands studied, there seems to be a trend for increased amounts in the stands of 10 and 40 years of age compared to those of 20 . The higher amount of organic matter in the 10 year-old stands can be attributed to the cultivation techniques (negative selection) practiced at the age of 7 which resulted in the addition of large amounts of plant residues that gradually (by decomposing) increased the content of organic matter in the soil of these stands. Plant residues include thin trunks and branches left on the forest floor after the removal of the useful plant material. Many research works refer to the large amounts of plant residues left on a site after clear-logging and stand thinning (Covington, 1981). The most crucial factor for the fast decomposition and the supplementation of the soil with nutrients is the raised temperature of the logged surfaces by being exposed to the sun which along with the appropriate levels of humidity accelerates decomposition of the plant material left on the site (Duchaufour, 1982).

On the contrary, the lower amount of organic matter in the 20 year-old stands are probably due to slower rates of decomposition and the nature of plant residues as some of them are accumulated on soil surface up to now. In this case a large part of this plant material (trunks, branches) is of bigger dimensions and has not fully been decomposed yet. Moreover plant residues left at the site after the posi- tive selection at the age of 15 differ in synthesis and quality in relation to those after the thinning at the age of 7 . Additionally it should be taken into account the high resistance of chestnut wood to decay and decomposition (Papaioannou et al., 2011). The high amounts of organic matter in the stands of 40 years old are mainly attributed to the high annual production of plant residues and the optimal decomposition conditions occurring at these stands (Papaioannou et al., 2011). Nitrogen amounts seem to follow almost the same trend with organic matter (Fig. 7) without any statistical differences among the studied stands. Thus high amounts of $\mathrm{N}$ were observed in the 10 and 40 yearold stands and low in those of 20 years old. This was an expected result given a well known relation of organic matter and nitrogen amounts in forest soils (Alifragis, 2008).

Concerning P (Fig. 7), it seems that in spite the fact that no significant differences were observed, the amounts of $\mathrm{P}$ are at high levels at the age of 10, medium at the age of 40 and lower at the age of 20 . These slight differences can be attributed, as in the case of nitrogen, to the presence of different organic matter amounts in the three age classes studied and not to minor differentiations of the parent material content in $\mathrm{P}$ observed from site to site (Tandos and Papaioannou, 1999). The statistical differences observed in the amounts of $\mathrm{Ca}(\mathrm{F}=6.211, p=0.035)$ 


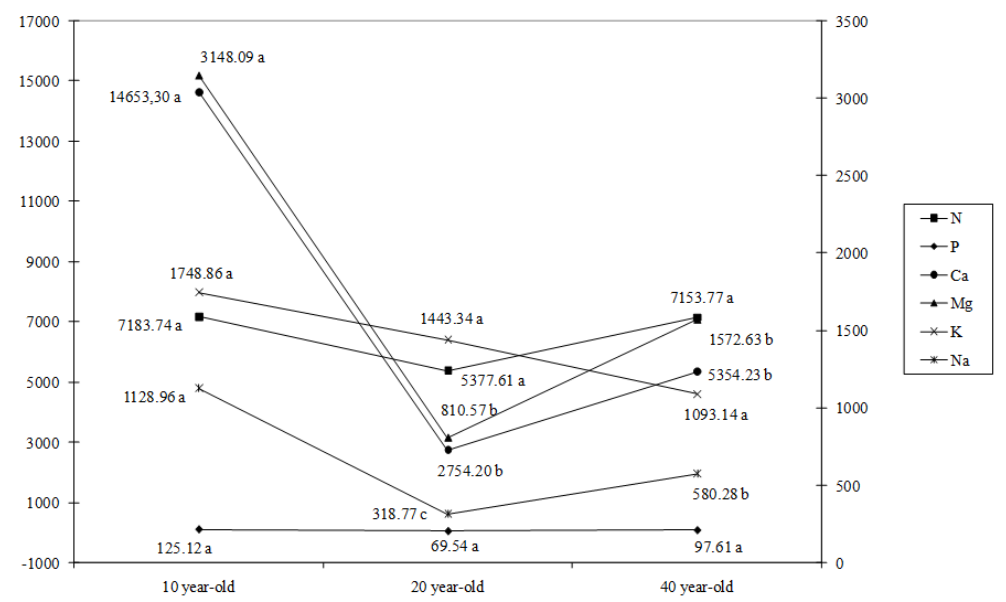

Fig. 7. N, P, Ca, Mg, K and $\mathrm{Na}$ amounts (kg/ha) in the mineral soil

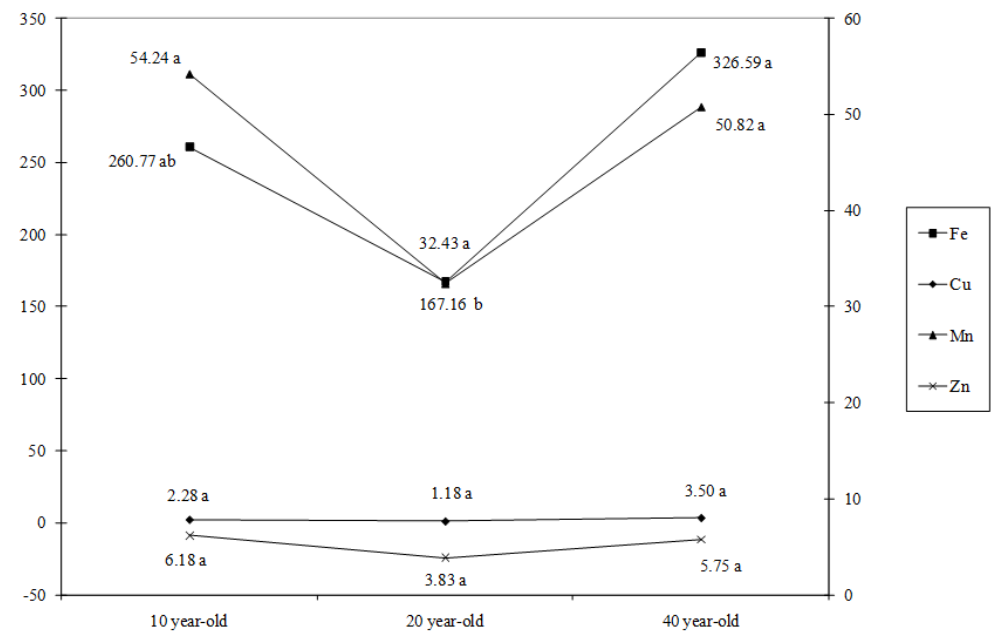

Fig. 8. Fe, $\mathrm{Cu}, \mathrm{Mn}$ and $\mathrm{Zn}$ amounts $(\mathrm{kg} / \mathrm{ha})$ in the mineral soil

and $\mathrm{Mg}(\mathrm{F}=10.221, p=0.012)$ showing the highest values at the age of 10 and the lowest at 20 year-old stands (Fig. 7) can be mainly attributed to the redistribution of these nutrients from the deeper to surface layers by the addition of plant residues resulting from clear-logging and secondly to minor differentiations observed from site to site in the parent material content (Papamichos, 2006). There were no significant differences in $\mathrm{K}$ amounts (Fig. 7). The statistical differences determined for $\mathrm{Na}(\mathrm{F}=56.984, p<0.001)$ might be due to the variable location of the slope in relation to air currents starting from sea level (Tsiontsis, 1991). Finally significant differences were recorded for $\mathrm{Fe}$ $(\mathrm{F}=6.86, p=0.036)$ showing high, medium and low values at the 40,10 and 20 year-old chestnut stands, respectively (Fig. 8). On the contrary, there were not detected any significant differences in heavy metal amounts $(\mathrm{Cu}, \mathrm{Mn}$ and $\mathrm{Zn}$ ) (Fig. 8) showing higher amounts at the ages of 10 and 40 comparing to those of 20 .

From all the above results it becomes obvious that in order to maintain soil fertility of chestnut ecosystems it is essential to increase rotation time from 20-22 years to the age the stands reach equilibrium i.e. at least 40 years old.

\section{Conclusions}

Similar amounts of organic matter were found on the forest floor in all three chestnut age groups while nutrient amounts (N, Ca, Mg, K, Fe, Cu, Mn and $\mathrm{Zn}$ ) were at low levels in the forest soil of 10 year-old chestnut stands by practicing the empirical management method under study to the coppice chestnut forests of Mount Athos in Greece. At the same time most of the nutrients such as: N, P, Ca, $\mathrm{Mg}, \mathrm{K}, \mathrm{Na}, \mathrm{Mn}$, and $\mathrm{Zn}$ were found in higher amounts in the inorganic soil of the same stands at the age of 10 . This point out the fact that the release rates of nutrients from the forest floor level to the inorganic soil are faster at the 10 year-old stands which can be attributed mainly to the origin of plant litter and the favorable conditions of decomposition. In general in the soil, high levels of both organic matter and nutrients are found mainly among the stands of 10 and 40 years with those of 10 year-old stump sprouts having the highest values.

From the evaluation of the results it is realized that even if the 10 year-old chestnut stands have undergone an intensive disruption form the beginning of stand establishment by clear-cut logging, the cultivation practices 
324

at the age of 7 (negative selection) have much increased plant residues on the inorganic soil surface. This resulted in the constant supplementation of the surface soil layers with nutrients and consequent retaining of soil fertility, at least until the age of 10-12. As chestnut stump sprouts grow and their requirements in nutrients increase, there is a reduction in the accumulation of nutrients in the soil of 20 year-old stands. The positive selection conducted at the age of 15 did not seem to supply the soil with adequate nutrients. This is may be due to the different synthesis and quality of plant litter left on soil surface at this age as it decomposes slowly having as a consequence lower nutrient release rates and reduced soil fertility.

The disruption caused firstly by clear-cut logging followed by negative selection at the age of 7 , continued by a positive selection at the age of 15 , is difficult to be restored when rotation time is set at 20-22 years. It is realized from the above results that in short term a severe degradation of soil resources will be observed at the coppice chestnut forests of Mount Athos with rotation periods of 20-22 years if the same empirical management method continues to be practiced. In order to overcome this situation we consider it a necessity to increase rotation time of 20-22 years to the age the stands reach equilibrium i.e. at least 40 years old.

\section{References}

Afif-Khouri E, Alvarez-Alvarez P, Fernandez-Lopez MJ, Oliveira-Prendes JA, Camara-Obregon A (2011). Influence of climate, edaphic factors and tree nutrition on site index of chestnut coppice stands in north-west Spain. Forestry 84:385-396.

Alifragis D (2008). The soil. Genesis-properties-classification. Vol. I. Aivazis Press, Thessaloniki, Greece (in Greek).

Alifragis D (2010). Description, sampling, laboratory analyses of forest soils and plant tissues. Aivazis Press, Thessaloniki, Greece (in Greek).

Athanasiadis N (1986). Forest Botany (trees and shrubs of the Greek forests). Part II. Giahoudis Giapoulis Press, Thessaloniki, Greece (in Greek).

Athanasiadis N (1996). Vegetation-Flora of the Holy Mountain - International Symposium 'The Holy Mountain YesterdayToday-Tomorrow?

Auclair AND, Renzc AN (1982). Concentration, mass and distribution of nutrients in a subarctic Picea mariana - Cladonia alpestris ecosystems. Can J For Res 12:947-968.

Austin AT, Vitousek PM (1998). Nutrient dynamics on a precipitation gradient in Hawaii. Oecologia 113:519-529.

Berthelot A, Ranger J, Gelhaye D (2000). Nutrient uptake and immobilization in short-rotation coppice of hybrid poplars in north-west France. For Ecol Manage 128:167-179.

Bourgeois C, Sevrin E, Lemaire J (2004). The Chestnut Tree and Wood. $2^{\text {nd }}$ revised Edn., Institut pour le Developpement Forestier, Paris.
Chen H (1998). Biomass and nutrient distribution in a Chinesefir plantation chronosequence in Southwest Hunan, China. For Ecol Manage 105:209-216.

Cole DW, Rapp M (1981). Elemental cycling in forest ecosystems, 341-409 p. In: Reichle DE (Ed.). Dynamic Properties of Forest Ecosystems, Cambridge University Press, London,

Cole DW, Ford ED, Turner J (1990). Nutrients, Moisture and Productivity of Established Forest. For Ecol Manage 30:283299.

Colin-Belgrand M, Ranger J, Bouchon J (1996). Internal nutrient translocation in chestnut tree stemwood. III. Dynamics across an age series of (Castanea sativa Miller). Ann Bot 78(6):729-740.

Cote B, Fyles JW, Djalivand H (2002). Increasing N and P resorption efficiency and proficiency in northern deciduous hardwoods with decreasing foliar $\mathrm{N}$ and $\mathrm{P}$ concentrations. Ann For Sci 59:275-281.

Covington WW (1981). Changes in forest floor organic matter and nutrient content during secondary succession following clear cutting in northern hardwoods. Ecology 62:41-48.

Duchaufour P (1982). Pedology: Pedogenesis and Classification. George Allen and Unwin, London.

Dyck WJ, Cole DW, Comerford NB (1994). Impacts of forest harvesting on long-term site productivity. Chapman and Hall, London.

Elliot KJ, Knoepp JD (2005). The effects of three regeneration harvest methods on plant diversity and soil characteristics in the southern Appalachians. For Ecol Manage 211:296-317.

Ganiatsas K (1963). Vegetation and flora of the Holy Mountain peninsula - State of Athos. Thessaloniki, 509-675 p.

Gilliam FS (2002). Effects of harvesting on herbaceous layer diversity of a central Appalachian hardwood forest in West Virginia, USA. For Ecol Manage 155:33-43.

Grant EG (1982). Exchangeable cations, 159-164 p. In: Page AL (Ed.). Methods of soil analysis, Part 2. Amer Soc Agr and Soil Sci Soc Ame, Madison, Wisconsin.

Hardtle W, von Oheimb G, Westphal C (2005). Relationships between the vegetation and soil conditions in beech and beech-oak forests of northern Germany. Plant Ecology 177:113-124.

Johnson DW, Todd DE Jr (1998). Harvest effects on long-term changes in nutrient pools of mixed oak forests. Soil Sci Soc Am J 62:1725-1735.

Kerr G, Evans J (1993). Growing Broad Leaves for Timber. Forestry Commission, London.

Larsen JB (1995). Ecological stability of forest and sustainable silviculture. For Ecol Manage 73:85-96.

Leonardi S, Santa Regina I, Rapp M, Gallego HA, Rico M (1996). Biomass, litterfall and nutrient content in Castanea sativa coppice stands of southern Europe. Ann For Sci 53:1071-1081.

Li Q, Moorhead DL, DeForest JL, Henderson R, Chen J, Jensen $\mathrm{R}$ (2009). Mixed litter decomposition in a managed Missouri 
Ozark forest ecosystem. For Ecol Manage 257:688-694.

Lindsay W, Norvell W (1978). Development of a DTPA soil test for zinc, iron, manganese and copper. Soil Sci Soc Am J 42:421-428.

Mauromatis GN (1980). Bioclimate of Greece. Relations between climate and natural vegetation. Bioclimatic maps. Forest research I (Appendix).

Moulopoulos C (1963). Silviculture of Mount Athos. State of Athos.

Moundrakis DM (1985). Geology of Greece. Thessaloniki.

National Forest Survey (1992). Greek Forest Service, Ministry of Agriculture, Athens.

Nelson DW, Sommers LE (1982). Total carbon, organic carbon and organic matter, 539-577 p. In: Page AL (Ed.). Methods of soil analysis, Part 2. American Society of Agronomy and Soil Science Society of America, Madison, Wisconsin.

Norusis M (2004). SPSS 13.0 Advanced Statistical Procedures Companion. Prentice Hall, Inc., Upper Saddle-River.

Palma RM, Defrieri RL, Tortarolo MF, Prause J, Gallardo JF (2000). Seasonal changes of bioelements in the litter and their potential return to green leaves in four species of the Argentine subtropical forest. Ann Bot 85:181-186.

Papaioannou AG (1993). Correlation of productivity with forms and characteristics of forest humus in black pine and beech forests in Northern Greece. Ph.D. Thesis, Thessaloniki, Greece (in Greek with English abstract).

Papaioannou A, Gakis S, Orfanoudakis M, Seilopoulos D, Kitikidou K, Pipinis I, Nikolaou G (2011). Effect of chestnut forest management upon the soil chemical properties in Mount Athos, Greece 15 Hellenic Forestry Conference, 6-18 October, Karditsa, Greece (in Greek).

Papamichos N (2006). Forest Soils. Aristotle University of Thessaloniki (in Greek).

Pernar N, Klimo ES, Matić SD, Bakšić DH, Lorencova H (2008). Different technologies of floodplain forest regeneration from the aspect of soil changes. J For Sci 55:357-367.

Rab MA (1996). Soil physical and hydrological properties following logging and slash burning in the Eucalyptus regnans forest of southeastern Australia. For Ecol Manage 84:159116.

Research Institute of Geology and Minerals (1978). Geologic map of Greece. Scale 1:50.000. Ierissos issue, Athos peninsula.

Roberts MR, Gilliam FS (1995). Patterns and mechanisms of plant diversity in forested ecosystems: implications for forest management. Ecol Appl 5(4):969-977.
Prats E, Vanrell P, Garcia C, Morey M (1991). Relation between the litter fall rate and its accumulation on the soil of a Pinus halepensis mill. forest in Majorca (Balearic islands, Spain), 688-690 p. In: Teller A, Mathy P, Jeffers JNR (Eds.). Responses of forest ecosystems to environmental changes, Elsevier Applied Science, London and New York.

Sariyildiz T, Anderson JM (2005). Variation in the chemical composition of green leaves and leaf litters from three deciduous tree species growing on different soil types. For Ecol Manage 210:303-319.

Schlesinger W (1990). Evidence from chronosequence studies for a low carbon-storage potential of soils. Nature 348:232234.

Smiris P (1991). Silviculture research of Chestnut forests. Sci Ann Dep Forestry and Natural Environ 15:410-427 (in Greek).

Stevenson FJ (1982). Nitrogen-organic forms, 625-641 p. In: Page AL (Ed.). Methods of soil analysis, Part 2. American Society of Agronomy and Soil Sci Soc Ame, Madison, Wisconsin.

Suc JP (1984). Origin and evolution of the Mediterranean vegetation and climate in Europe. Nature 307:429-432.

Tandos VA (1996). Dynamics of nutrient elements and production and distribution of organic matter recycling in a fir ecosystem (Abies-borisii regis, Matf.). Ph.D Thesis. Thessaloniki. (in Greek with English abstract).

Tandos V, Papaioannou AG (1999). Effect of the forest species on the accumulation and distribution of organic matter and nutrients on the forest floor. Proceedings of the $8^{\text {th }}$ Conference of the Greek Forest Science Society. April 6-8, 2000 Alexandroupoli, Greece. 129-138 p. (in Greek with English abstract).

Tsiontsis A (1991). Production and distribution of organic matter and dynamics of nutrients in a black pine ecosystem $(P i-$ nus nigra Arn). Ph.D. Thesis, Thessaloniki, Greece (in Greek with English abstract).

Vitousek PM (1997). Foliar and litter nutrients, nutrient resorption, and decomposition in Hawaiian (Metrosideros polymorpha). Ecosystems 1:401-407.

Walmsley JD, Jones DL, Reynolds B, Price MH, Healey JR (2009). Whole tree harvesting can reduce second rotation forest productivity. For Ecol Manage 257:1104-1111.

Word Reference Base for Soil Resources (1998). FAO. Rome. World Soil Resources. Reports 84.

Zhang S, Allen HL (1996). Foliar nutrient dynamics of 11-yearold loblolly pine (Pinus teada) following nitrogen fertilization. Can J For Res 26:1426-1439. 